\title{
Evidence That an Acute Increase in Glomerular Filtration Has Little Effect on Sodium Excretion in the Dog unless Extracellular Volume Is Expanded*
}

\author{
Marshall D. Lindheimer, $\nmid$ Richard C. Lalone, and Norman G. Levinsky \\ (From the Fifth and Sixth [Boston University] Medical Services, Boston City Hospital, and \\ the Department of Medicine, Boston University School of Medicine, Boston \\ University Medical Center, Boston, Mass.)
}

\begin{abstract}
Summary. The concept that acute increases in glomerular filtration rate (GFR) will cause large concomitant increases in sodium excretion has been re-examined. In previous work, GFR was elevated by volume expansion, usually with saline infusions. Recent evidence shows that tubular reabsorption is depressed during saline loading; hence, the independent effect of increased GFR on sodium excretion cannot be assessed.

To determine the effect of acute increases in GFR per se on sodium excretion, we raised GFR by four techniques not involving volume expansion: protein feeding, dopamine infusion, intravenous dexamethasone, and crosscirculation. GFR increased acutely by 5 to $85 \%$ in these experiments. In 12 of 24 experiments, GFR increased by more than $30 \%$. In all but one experiment, sodium excretion increased by less than $75 \mu \mathrm{Eq}$ per minute. Data from experiments using each of the four techniques were comparable. The results were the same whether mineralocorticoid activity was high or low. In contrast, during saline loading, sodium excretion increased more than $800 \mu \mathrm{Eq}$ per minute with equal or lesser changes in GFR.

These results demonstrate that acute increases in GFR per se have little effect on sodium excretion. We suggest that, due to constant fractional sodium reabsorption in the proximal tubule (glomerulotubular balance) and increased distal reabsorption, virtually all of the increase in filtered sodium is reabsorbed when GFR increases. Depression of tubular reabsorption is required for natriuresis.
\end{abstract}

\section{Introduction}

Since sodium excreted in the urine represents the difference between sodium filtered in the glomeruli and sodium reabsorbed by the tubules,

* Submitted for publication August 10, 1966; accepted October 27, 1966.

This study was supported in part by U. S. Publis Health Service research grants HE-06795, HE-09584, and AM-05589.

$\dagger$ Postdoctoral fellow (5-F2-HE-23 675) of the $\mathrm{Na}$ tional Heart Institute.

$\ddagger$ Established Investigator of the American Heart Association.

Address requests for reprints to Dr. Norman G. Levinsky, Boston University School of Medicine, $80 \mathrm{E}$. Concord St., Boston, Mass. 02118. changes in excretion necessarily result from changes either in filtered load or tubular reabsorption. In many instances, increases in the GFR and sodium excretion occur simultaneously, and, on theoretical grounds, increased filtered load must be considered an adequate explanation of increased sodium excretion (1). It is obvious, however, that parallel changes in load and excretion do not constitute experimental proof that an increase in load is, in fact, capable of causing increased excretion. Such reasoning, in the past, led to the assumption that the brisk natriuresis that follows saline loading in the dog is due to the increase in GFR that usually occurs. Recently, it has been clearly shown that part, at least, of the 
natriuresis is due to decreased tubular reabsorption $(2-4)$. These results indicate that the previous assumption that acute increases in GFR can cause natriuresis must be reconsidered, since this conclusion is based on experiments in which GFR was elevated by saline loading. Consequently, it seemed important to evaluate the effects on sodium excretion of acute increases in GFR induced by means other than saline loading.

To study this problem, we used three methods reported to raise filtration rate in the dog or other species : protein feeding $(5,6)$ and dexamethasone (7) and dopamine (8) administration. In addition, cross-circulation experiments were designed in which GFR was increased by plasma protein dilution without volume expansion. The results show that when tubular reabsorption is not depressed, large increases in GFR have negligible effects on sodium excretion.

\section{Methods}

Female mongrel dogs were studied both during the administration of large doses of mineralocorticoids and during blockade of mineralocorticoid activity by spironolactone. In preparation of the former group, food and water were withdrawn 18 hours before each experiment; at this time $5 \mathrm{U}$ of vasopressin tannate in oil and $10 \mathrm{mg}$ of deoxycorticosterone acetate (DOCA) were injected intramuscularly. An additional $5 \mathrm{mg}$ of DOCA was in- jected $\frac{1}{2}$ hour before each study. The latter group was fed $225 \mathrm{mg}$ of spironolactone ${ }^{1}$ daily in divided doses for 3 to 5 days before experiments. Supplemental salt was added to the diet of these dogs, and their weight was checked to ensure constancy. One hour before the experiment an additional $100 \mathrm{mg}$ of spironolactone was given, and in procedures involving unanesthetized animals a second dose was given 3 to 4 hours later.

Dogs were studied either unanesthetized, while standing supported by a halter, or during light pentobarbital anesthesia. Urine was collected from an indwelling bladder catheter. An intravenous infusion of either inulin or creatinine and $p$-aminohippurate (PAH) in water was maintained at a rate of approximately $0.5 \mathrm{ml}$ per minute. In each experiment, three to five control periods were obtained after sodium excretion had become stable at a rate of less than $100 \mu \mathrm{Eq}$ per minute. GFR was then increased acutely by one of five different methods. 1) Protein feeding. Each dog was fed 100 to $200 \mathrm{~g}$ electrolyte-free casein, mixed with a sufficient amount of Crisco to facilitate force-feeding. Collection periods were resumed 30 minutes to 1 hour later and continued for up to 4 hours after feeding. 2) Dexamethasone. Eight to $10 \mathrm{mg}$ of dexamethasone-21-phosphate was injected intravenously. Collection periods were continued over the next 2 to $2 \frac{1}{2}$ hours. 3) Dopamine. After the control periods, dopamine was added to the sustaining infusion. In each experiment, three rates of infusion were used: 10,15 , and $20 \mu \mathrm{g}$ per $\mathrm{kg}$ per minute. Three to six collections were made at each dose level. In some experiments, blood pressure was monitored via a catheter inserted into the femoral or carotid artery.

${ }^{1}$ Aldactone, G. D. Searle, Chicago, Ill.

TABLE I

Representative protein-feeding experiment*

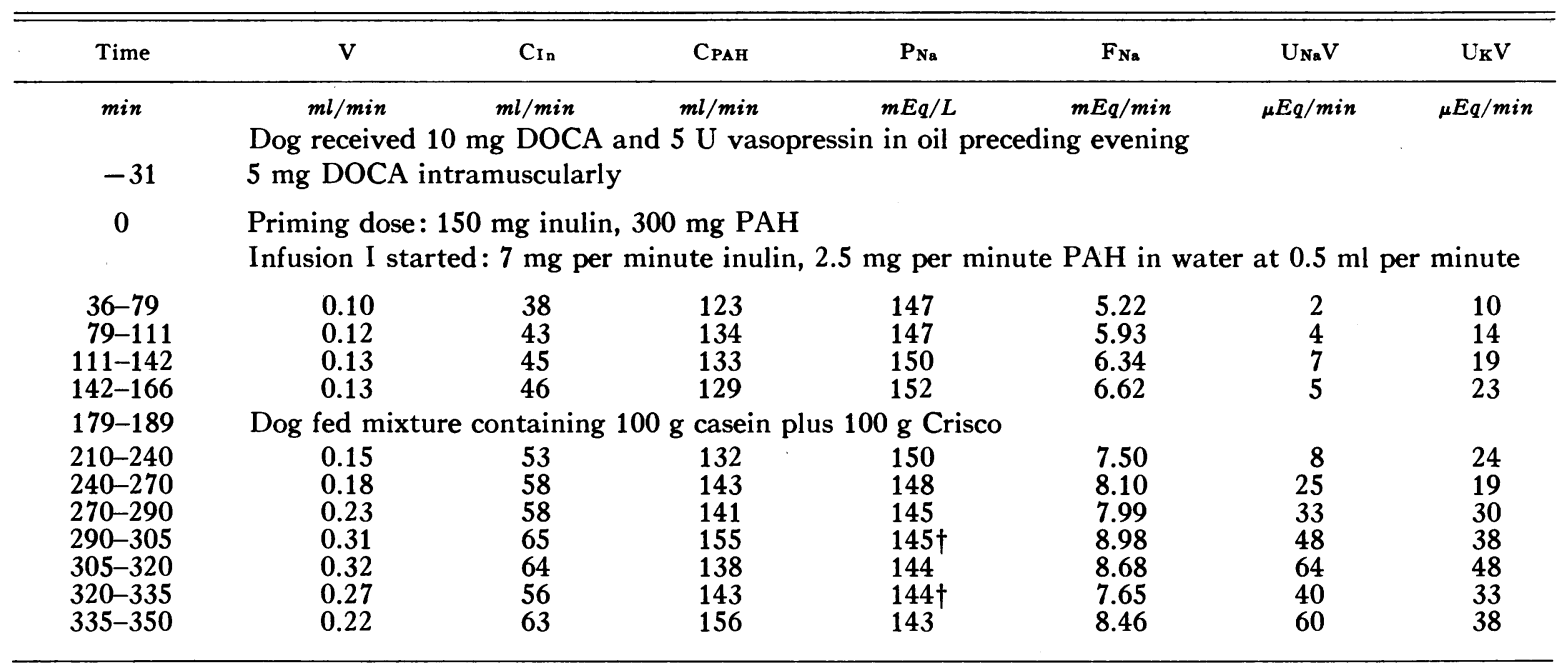

* Abbreviations are as follows: $\mathrm{V}=$ urine flow; $\mathrm{C}_{\mathrm{In}}=$ inulin clearance; $\mathrm{C}_{\mathrm{PAB}}=$ p-aminohippurate clearance $\mathrm{P}_{\mathrm{Na}}=$ plasma sodium; $\mathrm{F}_{\mathrm{Na}}=$ filtered sodium; $\mathrm{U}_{\mathrm{Na}} \mathrm{V}=$ sodium excretion; $\mathrm{U}_{\mathrm{K}} \mathrm{V}=$ potassium excretion; $\mathrm{DOCA}=\mathrm{de}-$ oxycorticosterone acetate.

† Interpolated value. 
4) Cross-circulation. The circulations of two lightly anesthetized dogs were joined via two shunts, each from an internal carotid artery of one to an external jugular vein of the other. Blood was either pumped or allowed to run freely from the first dog (donor) to the second. The second dog (recipient) was placed on a balance and its weight kept constant throughout the experiment by controlling the outflow of blood from its carotid shunt with a clamp. When sodium excretion in both dogs was stable and less than $50 \mu \mathrm{Eq}$ per minute, two to three control periods were taken in each dog. The donor dog was then infused with $1,500 \mathrm{ml}$ of saline, after which three to five more periods were collected from each dog. 5) Saline infusion. After the control periods, an infusion of $0.82 \%$ saline was started. The saline was initially infused at the rate of $30 \mathrm{ml}$ per minute until $400 \mathrm{ml}$ had been given; then the rate was decreased to 10 to $12 \mathrm{ml}$ per minute. When $1,800 \mathrm{ml}$ had been infused, three to five additional clearance collections were made. By the end of the collections a total of approximately 2,100 ml had been infused.

Analytical methods used in this laboratory have been described elsewhere (3). The calculation of filtered sodium includes a correction for the Donnan factor. Each value in summary Tables and Figures is the mean of at least three periods during which GFR and sodium excretion were relatively stable. Since the purpose of these experiments was to examine the effect of acute increases in GFR on sodium excretion, a number of experiments in which GFR did not increase have not been included in the presentation of data.

\section{Results}

Protein feeding. The protocol of a representative protein experiment is given in Table I. After the casein feeding, GFR rose from a control value of $43 \mathrm{ml}$ per minute to a relatively stable value of $62 \mathrm{ml}$ per minute during the final four periods collected 2 hours later, an increase of $45 \%$. Whereas filtered sodium increased $2.42 \mathrm{mEq}$ per minute, from 6.02 to $8.44 \mathrm{mEq}$ per minute, sodium excretion rose only $49 \mu \mathrm{Eq}$ per minute, from 5 to $54 \mu \mathrm{Eq}$ per minute. Ten groups of collection periods were obtained in nine experiments, and the data are summarized in Table II and Figure 1.

TABLE II

Summary of experiments*

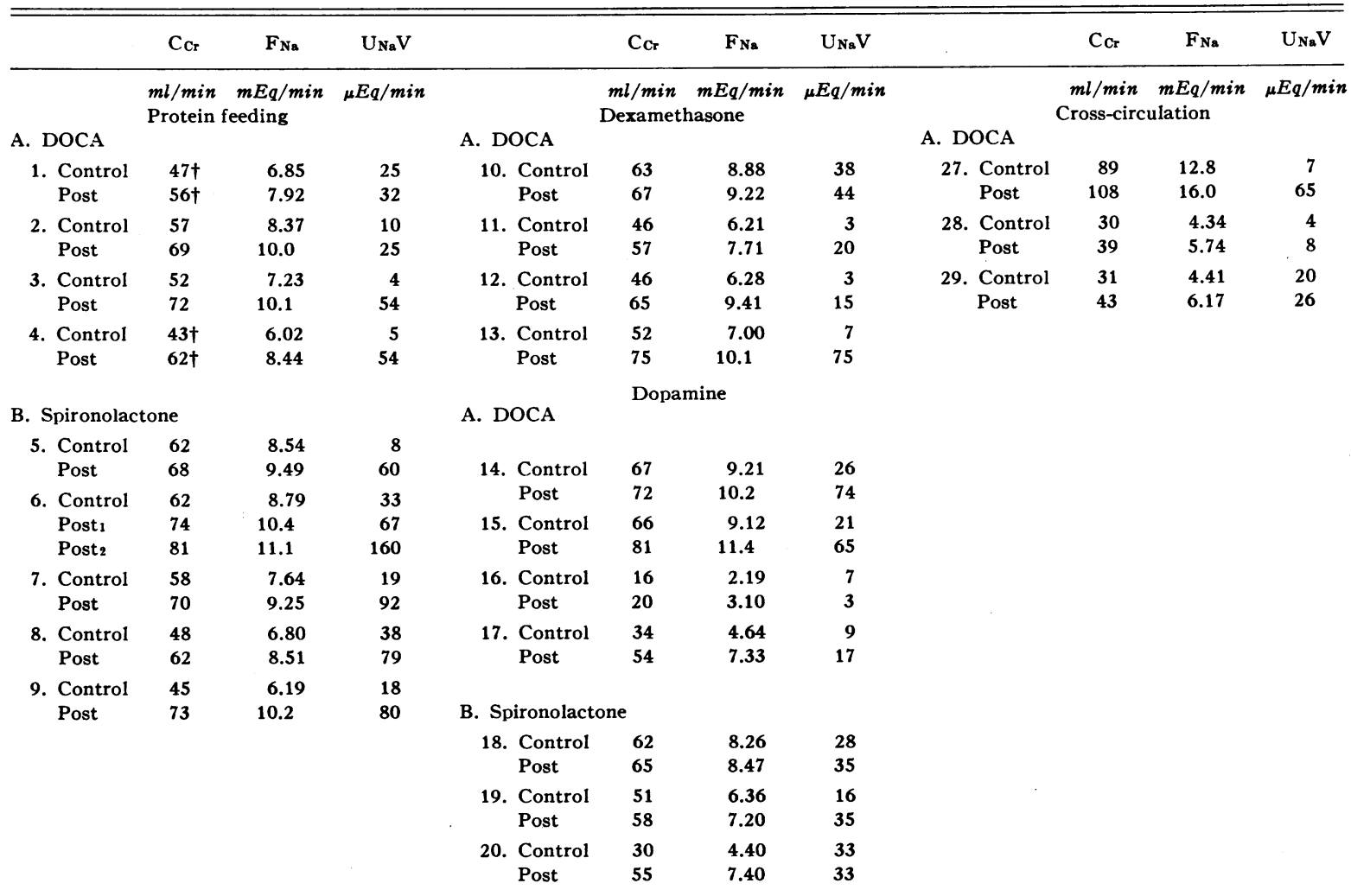

$* \mathrm{C}_{\mathrm{Cr}}=$ creatinine clearance. Post $=$ mean of three or more stable periods after experimental manipulation. Other abbreviations as in Table I.

† Inulin clearance. 


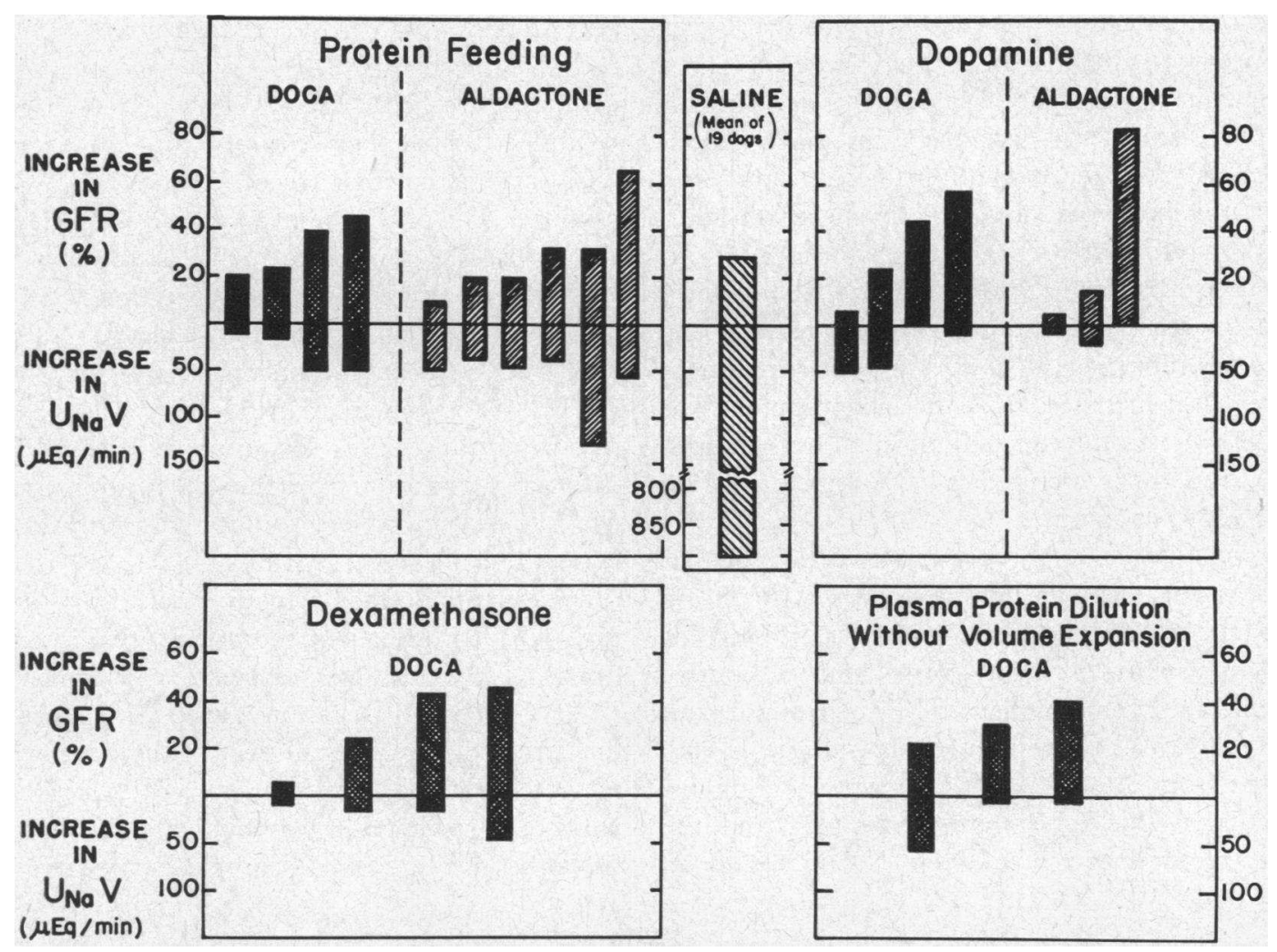

Fig. 1. Summary of individual experiments. Each bar represents the difference between experimental and control periods in one experiment. Increase in glomerular filtration rate (GFR) is plotted up and increase in sodium excretion $\left(\mathrm{U}_{\mathrm{Na}} \mathrm{V}\right)$ down from the zero line. DOCA = deoxycorticosterone acetate $;$ Aldactone $=$ spironolactone.

TABLE III

Representative dexamethasone experiment*

\begin{tabular}{|c|c|c|c|c|c|c|c|}
\hline Time & $\mathrm{V}$ & $\mathrm{C}_{\mathrm{Cr}}$ & С & $\mathbf{P}_{\mathrm{Na}}$ & $\mathrm{F}_{\mathrm{Na}}$ & $\mathrm{U}_{\mathrm{NaV}}$ & $\mathrm{UKV}_{\mathbf{K}} \mathrm{V}$ \\
\hline $\min$ & $m l / m i n$ & $m l / m i n$ & $m l / m i n$ & $m E q / L$ & $m E q / \min$ & $\mu E q / \min$ & $\mu E q / \min$ \\
\hline-30 & \multicolumn{7}{|c|}{$\begin{array}{l}\text { Dog received } 10 \mathrm{mg} \text { DOCA and } 5 \mathrm{U} \text { vasopressin in oil preceding evening } \\
5 \mathrm{mg} \text { DOCA intramuscularly }\end{array}$} \\
\hline 0 & \multicolumn{7}{|c|}{$\begin{array}{l}\text { Priming dose : } 300 \mathrm{mg} \text { creatinine, } 115 \mathrm{mg} \mathrm{PAH} \\
\text { Infusion I started: } 12.5 \mathrm{mg} \text { per minute creatinine, } 2.5 \mathrm{mg} \text { per minute } \mathrm{PAH} \text { in water at } 0.5 \mathrm{ml} \text { per minute }\end{array}$} \\
\hline $\begin{array}{l}42-54 \\
54-64 \\
64-74 \\
74-95\end{array}$ & $\begin{array}{l}0.18 \\
0.17 \\
0.18 \\
0.20\end{array}$ & $\begin{array}{l}47 \\
47 \\
45 \\
47\end{array}$ & $\begin{array}{l}112 \\
115 \\
115 \\
122\end{array}$ & $\begin{array}{l}144 \\
143 \dagger \\
141 \\
140\end{array}$ & $\begin{array}{l}6.34 \\
6.28 \\
5.99 \\
6.22\end{array}$ & $\begin{array}{l}2 \\
2 \\
3 \\
4\end{array}$ & $\begin{array}{l}4 \\
5 \\
4 \\
4\end{array}$ \\
\hline 101 & \multicolumn{5}{|c|}{$8 \mathrm{mg}$ of dexamethasone-21-phosphate, intravenously } & & \\
\hline $\begin{array}{l}120-135 \\
135-150 \\
150-165 \\
165-180 \\
180-195 \\
195-205 \\
205-215\end{array}$ & $\begin{array}{l}0.19 \\
0.23 \\
0.33 \\
0.40 \\
0.33 \\
0.40 \\
0.39\end{array}$ & $\begin{array}{l}50 \\
51 \\
56 \\
56 \\
58 \\
58 \\
58\end{array}$ & $\begin{array}{l}136 \\
140 \\
153 \\
152 \\
164 \\
156 \\
157\end{array}$ & $\begin{array}{l}143 \\
143 \dagger \\
143 \\
143 \dagger \\
142 \\
143 \dagger \\
143\end{array}$ & $\begin{array}{l}6.69 \\
6.90 \\
7.51 \\
7.61 \\
7.79 \\
7.80 \\
7.86\end{array}$ & $\begin{array}{r}3 \\
5 \\
13 \\
31 \\
26 \\
18 \\
11\end{array}$ & $\begin{array}{r}4 \\
4 \\
11 \\
16 \\
14 \\
10 \\
8\end{array}$ \\
\hline
\end{tabular}

* Abbreviations as in previous Tables.

$\dagger$ Interpolated value. 
Since no significant difference was noted between dogs prepared with DOCA and those prepared with spironolactone, data from all the experiments have been considered together. In most experiments GFR rose acutely within the first hour, and the maximal increase occurred by the third hour. Filtration rate increased acutely by 9 to $62 \%$ after feeding; the mean rise was $30 \%$. The simultaneous increase in sodium excretion was less than $75 \mu \mathrm{Eq}$ per minute in all studies except experiment 6 , in which it increased $127 \mu \mathrm{Eq}$ per minute. The mean increase in filtered sodium in all experiments was $2.02 \mathrm{mEq}$ per minute and in sodium excretion was $53 \mu \mathrm{Eq}$ per minute.

Dexamethasone. A representative dexamethasone protocol is shown in Table III. After $8 \mathrm{mg}$ of dexamethasone phosphate had been infused intravenously, filtration rate rose from a control value of $46 \mathrm{ml}$ per minute to $57 \mathrm{ml}$ per minute, an increase of $23 \%$. Simultaneously sodium excretion rose from 3 to $20 \mu \mathrm{Eq}$ per minute. Four experiments of this type were performed, and the results are summarized in Table II and Figure 1.
The filtration rate rose between 5 and $45 \%$; the mean increase was $29 \%$. Whereas mean filtered sodium increased $2.02 \mathrm{mEq}$ per minute, mean sodium excretion increased only $26 \mu \mathrm{Eq}$ per minute. The largest increase recorded was $68 \mu \mathrm{Eq}$ per minute. The effect of dexamethasone on the filtration rate was immediate; GFR was stable at the higher level by 1 hour after injection.

Dopamine. In Table IV data from a representative dopamine infusion experiment are recorded. The control filtration rate was $30 \mathrm{ml}$ per minute; infusion of dopamine at 130, 195, and $260 \mu \mathrm{g}$ per minute produced filtration rates of 51,51 , and $55 \mathrm{ml}$ per minute, respectively. Despite these increases of up to $85 \%$ in GFR, sodium excretion was virtually unchanged, increasing only $53 \mu \mathrm{Eq}$ per minute at the maximum. Seven dopamine studies were performed with DOCA-prepared dogs and three with spironolactone-treated dogs. The effect of the drug was immediate; a stable elevation of GFR was obtained within 15 minutes. Although there was some variation, the highest GFR usually occurred dur-

TABLE IV

Representative dopamine experiment*

\begin{tabular}{|c|c|c|c|c|c|c|c|}
\hline Time & $\mathbf{V}$ & $\mathrm{C}_{\text {In }}$ & CPAH & $P_{\mathrm{Na}}$ & $\mathbf{F}_{\mathrm{Na}}$ & $\mathrm{UNa}_{\mathrm{Na}} \mathrm{V}$ & $\mathbf{U}_{\mathbf{K}} \mathbf{V}$ \\
\hline $\min$ & $\quad m l / \min$ & $m l / m i n$ & $m l / m i n$ & $m E q / L$ & $m E q / \min$ & $\mu E q / \min$ & $\mu E q / \min$ \\
\hline-75 & \multicolumn{7}{|c|}{$\begin{array}{l}\text { Dog received } 225 \mathrm{mg} \text { per day of spironolactone orally for } 5 \text { days plus supplemental salt } \\
100 \mathrm{mg} \text { spironolactone orally }\end{array}$} \\
\hline 0 & \multicolumn{7}{|c|}{$\begin{array}{l}\text { Priming dose: } 500 \mathrm{mg} \text { creatinine, } 100 \mathrm{mg} \text { PAH } \\
\text { Infusion I started: } 12.5 \mathrm{mg} \text { per minute creatinine, } 2.5 \mathrm{mg} \text { per minute PAH at } 0.5 \mathrm{ml} \text { per minute }\end{array}$} \\
\hline $\begin{array}{l}34-39 \\
49-68 \\
68-78\end{array}$ & $\begin{array}{l}0.25 \\
0.21 \\
0.25\end{array}$ & $\begin{array}{l}31 \\
28 \\
31\end{array}$ & $\begin{array}{l}96.5 \\
68.2 \\
87.0\end{array}$ & $\begin{array}{l}148 \\
148 \\
149\end{array}$ & $\begin{array}{l}4.32 \\
3.90 \\
4.32\end{array}$ & $\begin{array}{l}34 \\
27 \\
33\end{array}$ & $\begin{array}{l}5 \\
5 \\
6\end{array}$ \\
\hline 91 & \multicolumn{7}{|c|}{ Dopamine, $260 \mu \mathrm{g}$ per $\mathrm{ml}$, added to infusion $\mathrm{I}$} \\
\hline $\begin{array}{l}124-132 \\
132-140 \\
140-149\end{array}$ & $\begin{array}{l}0.61 \\
0.63 \\
0.65\end{array}$ & $\begin{array}{l}49 \\
54 \\
50\end{array}$ & $\begin{array}{l}137 \\
153 \\
141\end{array}$ & $\begin{array}{l}147 \\
147 \dagger \\
146\end{array}$ & $\begin{array}{l}6.78 \\
7.47 \\
6.91\end{array}$ & $\begin{array}{l}83 \\
84 \\
85\end{array}$ & $\begin{array}{r}9 \\
9 \\
12\end{array}$ \\
\hline 152 & \multicolumn{7}{|c|}{ Dopamine concentration in infusion increased to $390 \mu \mathrm{g}$ per $\mathrm{ml}$} \\
\hline $\begin{array}{l}164-171 \\
171-177 \\
177-184 \\
184-192 \\
192-209\end{array}$ & $\begin{array}{l}0.64 \\
0.60 \\
0.73 \\
0.61 \\
0.55\end{array}$ & $\begin{array}{l}53 \\
49 \\
53 \\
51 \\
49\end{array}$ & $\begin{array}{l}106 \\
114 \\
134 \\
135 \\
147\end{array}$ & $\begin{array}{l}144 \\
145 \dagger \\
145 \\
146 \dagger \\
146\end{array}$ & $\begin{array}{l}7.08 \\
6.60 \\
7.13 \\
6.91 \\
6.66\end{array}$ & $\begin{array}{l}88 \\
77 \\
72 \\
56 \\
44\end{array}$ & $\begin{array}{l}14 \\
14 \\
14 \\
13 \\
13\end{array}$ \\
\hline 204 & \multicolumn{7}{|c|}{ Dopamine concentration in infusion increased to $520 \mu \mathrm{g}$ per $\mathrm{ml}$} \\
\hline $\begin{array}{l}217-226 \\
226-235 \\
235-245\end{array}$ & $\begin{array}{l}0.50 \\
0.50 \\
0.48\end{array}$ & $\begin{array}{l}\mathbf{5 4} \\
55 \\
56\end{array}$ & $\begin{array}{l}152 \\
139 \\
128\end{array}$ & $\begin{array}{l}145 \\
146 \dagger \\
147\end{array}$ & $\begin{array}{l}7.38 \\
7.08 \\
7.68\end{array}$ & $\begin{array}{l}37 \\
32 \\
30\end{array}$ & $\begin{array}{l}19 \\
19 \\
21\end{array}$ \\
\hline
\end{tabular}

* Abbreviations as in previous Tables.

† Interpolated value. 


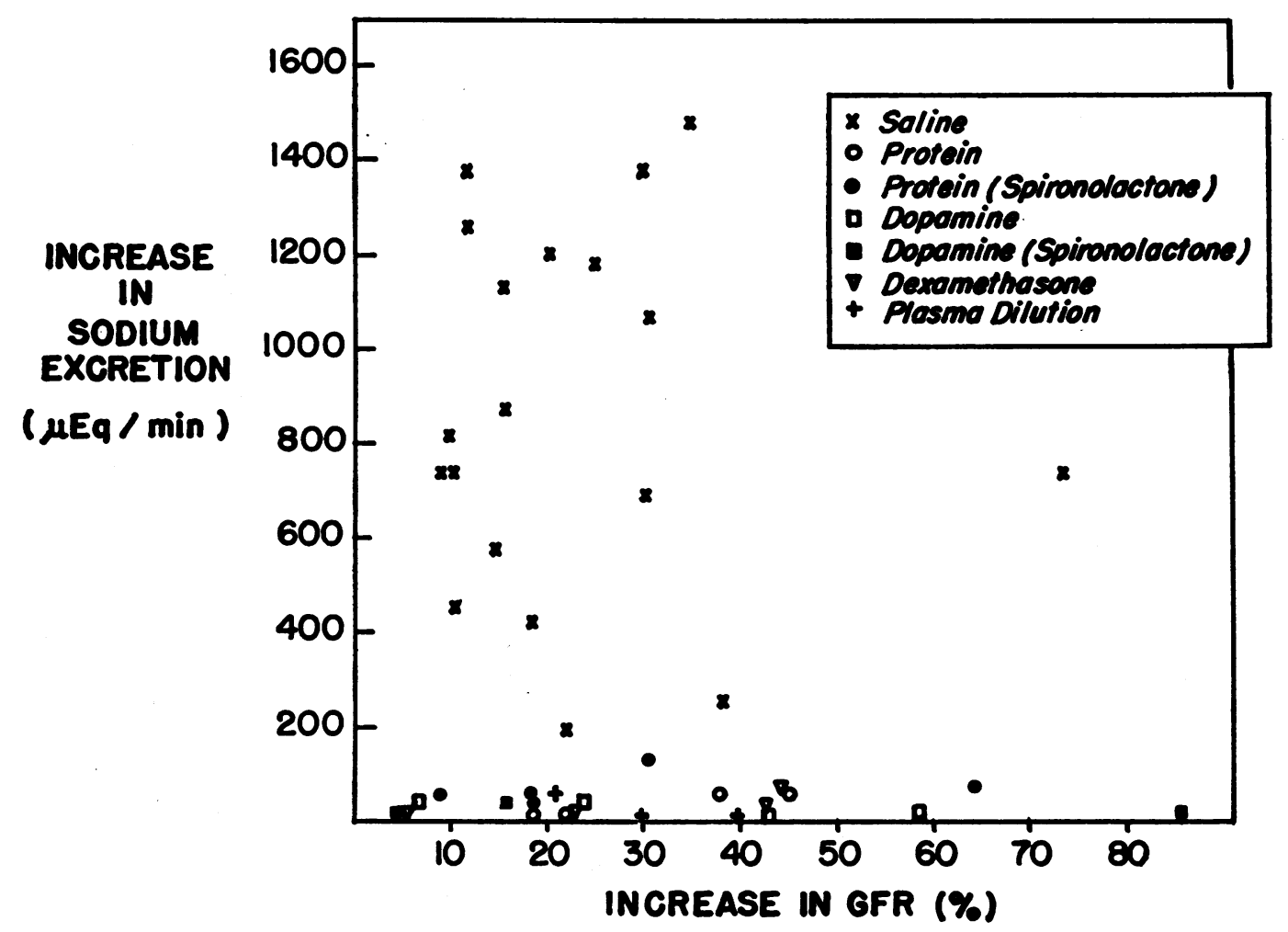

Fig. 2. MASS Plot OF DATA FROM ALl EXPERIMENTs. Each point represents the change in sodium excretion and GFR in the experimental relative to the control periods in a single experiment.

ing the largest dose. The largest increment in GFR was usually obtained with the first dose (10 $\mu \mathrm{g}$ per $\mathrm{kg}$ per minute); doubling the dose produced only small additional rises. The data are summarized in Table II and Figure 1. Filtration rates rose by 5 to $85 \%$; the mean increase was $34 \%$. The mean increases in filtered and excreted sodium were $1.53 \mathrm{mEq}$ per minute and $17 \mu \mathrm{Eq}$ per minute, respectively. In the three dogs in which the blood pressure was monitored, changes during dopamine infusion were less than $10 \mathrm{~mm} \mathrm{Hg}$ and were variable in direction.

Cross-circulation. Three experiments were performed in which GFR increased acutely during cross-circulation of a test dog with a salineloaded dog. When cross-perfusion was in progress, saline loading of one dog resulted in hemodilution of both dogs. By keeping the weight of the test dog constant, we were able to hemodilute this dog without volume expansion. The effect of the cross-circulation on the filtration rate of the test dog was variable; GFR decreased in four and changed little in two experiments. In the three experiments summarized in Table II and Figure 1, GFR rose 21,30 , and $39 \%$, respectively. Despite an increase in filtered sodium of $1.4,1.8$, and 3.2 $\mathrm{mEq}$ per minute, sodium excretion increased less than $60 \mu \mathrm{Eq}$ per minute in each experiment.

Saline loading. To compare with the effects of increases in GFR produced by the techniques described above, 19 experiments in which saline infusion raised GFR are summarized in Figures 1 and 2. The mean increases in filtration rate, filtered sodium, and excreted sodium were $28 \%$, $1.85 \mathrm{mEq}$ per minute, and $871 \mu \mathrm{Eq}$ per minute, respectively. In Figure 2, it is seen that virtually all points from the saline-loading experiments are well above those from any of the other methods, indicating markedly higher sodium excretion with comparable increases in GFR during saline loading. It should be noted that in 12 of 24 experiments in which glomerular filtration was raised by means other than saline loading, GFR increased by more than $30 \%$; in all but one of these, sodium excretion increased less than $75 \mu \mathrm{Eq}$ per minute. In contrast, increases in filtration rate induced 
by saline loading were less than $30 \%$ in 13 of 19 experiments; nevertheless, sodium excretion increased more than $400 \mu \mathrm{Eq}$ per minute in all but two saline studies.

\section{Discussion}

The data demonstrate that marked increases in GFR induced by four methods other than saline loading have little effect on sodium excretion. These observations are at variance with the concept that acute increases in filtered sodium per se will cause large concomitant increases in sodium excretion (1). Although this concept is theoretically reasonable, the experimental evidence on which it was based is of two types, neither of which can be accepted as proof of the thesis in the light of present knowledge. One line of argument is based on the strong experimental evidence that decreases in GFR lead to diminished sodium excretion $(1,3,9,10)$. It is obvious a priori that extrapolation from the effects of decreased GFR to those of increased GFR cannot be accepted uncritically. Furthermore, the means used to lower GFR such as aortic obstruction $(3,9)$ or hemorrhage (10) may themselves alter tubular sodium reabsorption. The other line of evidence is based on experiments in which GFR was increased by infusion of saline or other solutions that expand extracellular volume. In view of the recent work which demonstrates that saline infusion strikingly depresses tubular reabsorption of sodium (2-4) at a proximal site (11), studies involving saline infusion are obviously unsatisfactory for determining the independent effect of increased GFR on sodium excretion. The results of the present experiments indicate that acute increases in GFR have little effect on sodium excretion if tubular reabsorption is not depressed.

It might be argued that each of the methods used to increase GFR acutely also directly enhances tubular reabsorption to a proportionate degree. Considering the variety of methods employed with similar results, this would seem unlikely a priori. The mechanism by which protein feeding increases GFR is unknown; the fact that glycine has a similar effect on renal hemodynamics (12) suggests that the action of protein is due to its amino acid content. Whatever the mechanism of the hemodynamic action, there is no evidence that protein enhances tubular reabsorptive capacity for sodium. On the contrary, sodium excretion increases promptly when dogs are fed a protein meal that contains salt (5) or infused with glycine in saline (13). This suggests that protein and amino acids do not interfere with the depression of tubular reabsorption by salt feeding or saline infusion. The renal actions of dopamine are incompletely understood, but dopamine causes an impressive natriuresis and a large rise in GFR in man (8). Although GFR in the dog increased as much in our experiments as in man, sodium excretion rose only slightly. The reason for this striking species difference is unknown. However, the human data would suggest that, if dopamine has any effect on tubular reabsorption of sodium, it is to decrease reabsorptive capacity. It is possible that dexamethasone and cross-circulation may enhance tubular reabsorption to some extent. Although it is generally considered to be virtually without sodium-retaining activity (14), dexamethasone in the large doses used in our experiments might possibly enhance tubular reabsorption of sodium. No specific information on this point is available. It should be noted, however, that the dogs given dexamethasone had been pretreated with large amounts of DOCA. To the (unknown) extent that any antinatriuretic actions of large doses of dexamethasone overlap in mechanism of tubular action with those of mineralocorticoids, any sodium-retaining action of dexamethasone would have been diminished by our protocol. In the cross-circulation procedure we used, plasma protein concentration and red cell mass in the recipient (test) dog fall when saline is infused into the donor dog. Therefore, the recipient probably suffers some decrease in intravascular volume (2), which may enhance tubular reabsorption of sodium (15). The extent and significance of this effect under the conditions of our experiments are unknown. However, it should be stressed that the results of the cross-circulation and dexamethasone experiments are entirely analogous to the protein feeding and dopamine studies. This suggests that direct enhancement of tubular reabsorption by dexamethasone or cross-circulation either does not occur or is of minor significance in our experiments.

The level of mineralocorticoid activity had no influence on the results of these studies. The small increment in sodium excretion when GFR was increased acutely was the same when the dogs 
had been treated with large amounts of mineralocorticoids as when the action of aldosterone had been blocked with spironolactone. Endogenous aldosterone secretion presumably falls when dogs are infused with saline. Our data show, however, that even the combination of increased GFR and decreased aldosterone has little effect on sodium excretion when tubular reabsorption is not depressed.

Although increases in GFR have little effect on sodium excretion, other renal hemodynamic changes during saline infusion may be important. Recent work by Earley and Friedler (16-19) suggests that increased renal blood flow and arterial perfusion pressure may be critical factors in saline diuresis. In our studies, renal cortical plasma flow was estimated from $\mathrm{PAH}$ clearance in all but the cross-circulation experiments. Mean clearance of $\mathrm{PAH}$ increased $21 \mathrm{ml}$ per minute (12\%) after protein feeding, $43 \mathrm{ml}$ per minute (32\%) after dexamethasone, and $37 \mathrm{ml}$ per minute $(26 \%)$ during dopamine infusion. In previous studies in our laboratory, it was found that the effect of saline infusion on renal plasma flow varies with the rate of saline infusion (20). After infusion of $1,800 \mathrm{ml}$ of saline at $10 \mathrm{ml}$ per minute, $\mathrm{PAH}$ clearance increased $17 \mathrm{ml}$ per minute (9\%), and sodium excretion increased $950 \mu \mathrm{Eq}$ per minute. After infusion of $1,800 \mathrm{ml}$ of saline at 50 $\mathrm{ml}$ per minute, $\mathrm{PAH}$ clearance increased $60 \mathrm{ml}$ per minute $(26 \%)$, and sodium excretion increased by more than $1,700 \mu \mathrm{Eq}$ per minute. Thus, protein feeding, dexamethasone, and dopamine increase the clearance of $\mathrm{PAH}$ as much as or more than saline, yet sodium excretion increases markedly only with saline. These data indicate that increases in cortical plasma flow per se are not the critical factor in saline diuresis. We reached similar conclusions with respect to medullary blood flow from recent experiments in our laboratory (20). However, these data do not eliminate the possibility that more subtle changes in renal hemodynamics than those we measured are important in the natriuresis of saline loading. Arterial pressure was monitored only in a few dopamine studies, during which inconstant changes were noted. Earley and Friedler have proposed that perfusion pressure within the kidney may be an important determinant of natriuresis (19). It may well be that pressure changes in critical areas of the kidney during saline infusion are quite different from those that occurred in our experiments. It is also possible that distribution of an increase in GFR among groups of nephrons with varying sodium reabsorptive capacity determines the extent of the natriuresis that results. Most of the increment in GFR during saline infusion may be distributed to nephrons with limited reabsorptive capacity, whereas the increase in GFR with our other procedures might occur mostly in nephrons with greater capacity to reabsorb the additional filtered sodium. Finally, our results are obviously quite compatible with the view that saline diuresis is due to hormonal depression of tubular reabsorption (2). The postulated hormone would be released during volume loading with saline, but not during the administration of protein, dexamethasone, or dopamine, which presumably do not increase extracellular volume. ${ }^{2}$

Recent micropuncture studies (22-26) suggest strongly that fractional sodium reabsorption in the proximal tubule remains constant in the face of wide variations of GFR. This phenomenon is presumably the basis of the parallel variations in over-all tubular reabsorption of sodium when GFR changes that have long been recognized from clearance studies and designated glomerulotubular balance (1). In most micropuncture experiments, proximal glomerulotubular balance was demonstrated only during decreases in GFR produced by clamping the aorta or renal artery. Glomerulotubular balance during increases in GFR has been demonstrated only during hypertonic saline loading in the rat (23). However, in other studies in which GFR was elevated by hypertonic or isotonic saline loading in the rat (27) or dog (11), fractional sodium reabsorption in the proximal tubule decreased. The depression of fractional reabsorption is a specific effect of the saline loading, unrelated to changes in GFR (11). Because of this phenomenon, it is uncertain whether glomerulotubular balance persists when GFR is progressively increased.

2 The lack of natriuresis in the cross-circulation experiments is surprising, if a natriuretic hormone is released during saline loading. Other workers $(2,21)$ have reported that moderate natriuresis does occur in similar cross-circulation experiments. The interpretation of cross-circulation experiments with respect to tubular natriuretic hormones is moot and beyond the scope of the present discussion. 
The present data indicate, albeit indirectly, that this is probably the case. When GFR is elevated without volume expansion, sodium excretion is only slightly increased. We suggest that fractional reabsorption in the proximal tubule remains constant when GFR rises. Thus, a large fraction of the increment in filtered sodium, perhaps $80 \%$, is reabsorbed in the proximal segment. It has been demonstrated by micropuncture that sodium reabsorption in more distal tubular segments increases greatly when the rate of sodium delivery is increased. It is probable that the loop of Henle is the principal site of this phenomenon $(23,27)$. Presumably, virtually all of the extra sodium that escapes proximal reabsorption when GFR is elevated by our procedures is reabsorbed by the loop of Henle or more distal sites, thereby minimizing increases in urinary sodium. Although this formulation seems reasonable, micropuncture studies will be needed to demonstrate that fractional reabsorption in the proximal tubule is constant when GFR is increased by the procedures we used.

Although they demonstrate that increased GFR has little effect on sodium excretion in dogs in which volume has not been expanded, our data are not necessarily at variance with the concept that the magnitude of natriuresis during saline infusion is to some extent related to the magnitude of the increase in GFR $(1,3)$. Sodium excretion during saline diuresis decreases when GFR is reduced by aortic clamping, although it remains above control levels when GFR has been lowered to control (3). Of course, the decrease in sodium excretion during clamping may be due to extraneous factors introduced by the clamping procedure, such as decreased perfusion pressure, decreased renal blood flow in some critical area, or increased angiotensin activity, rather than to the decrease in GFR itself. However, proximal fractional sodium reabsorption, previously depressed by saline, does not change during aortic clamping (11). This observation suggests that it is the decrease in GFR rather than any tubular effect of the clamping procedure that accounts for the decrease in sodium excretion when the aorta is constricted in saline-loaded dogs. By extrapolation, these data would fit with the correlation between the magnitude of the increase in GFR and in sodium excretion noted in many clearance studies (1). Thus, an increase in GFR may be more ef- fective in promoting natriuresis in saline-loaded than in dehydrated dogs. The following explanation would seem reasonable. Fractional reabsorption in the proximal tubule decreases by about one-third after saline loading in dogs (11). The level of fractional reabsorption remains constant in both saline-loaded and dehydrated dogs as GFR is reduced by aortic clamping. If we assume that glomerulotubular balance is similarly maintained when GFR increases and that proximal fractional reabsorption is $75 \%$ in uninfused and $50 \%$ in saline-loaded dogs, a rise in GFR will increase the amount of sodium escaping the proximal tubule twice as much in a saline-loaded as in a dehydrated dog. Thus, distal capacity to reabsorb sodium may be more readily exceeded by increased GFR in saline-loaded dogs. Obviously, the present experiments offer no direct proof of this formulation. The effects of increases in GFR on fractional reabsorption may be quite different from those that result when GFR is decreased. Furthermore, decreased distal reabsorptive capacity during saline loading may be a factor, if increases in GFR have differing effects on sodium excretion in dogs in which volume has been expanded and those that have received no infusion. Appropriate micropuncture studies will be required to resolve these questions.

It should be emphasized that the present studies, in which GFR was elevated acutely, do not rule out chronic increase in GFR as a factor in eliminating large sodium loads. On the contrary, an increase of only $20 \mu \mathrm{Eq}$ per minute in sodium excretion, a rate well within the range noted in our acute studies, is equivalent to an increase of nearly $30 \mathrm{mEq}$ per day in sodium excretion. Whether chronic increases in GFR alone will, in fact, result in increased sodium excretion can only be determined by further experiments.

\section{References}

1. Wesson, L. G., Jr. Glomerular and tubular factors in the renal excretion of sodium chloride. Medicine (Baltimore) 1957, 36, 281.

2. De Wardener, H. E., I. H. Mills, W. F. Clapham, and C. J. Hayter. Studies on the efferent mechanism of the sodium diuresis which follows the administration of intravenous saline in the dog. Clin. Sci. 1961, 21, 249.

3. Levinsky, N. G., and R. C. Lalone. The mechanism of sodium diuresis after saline infusion in the dog. J. clin. Invest. 1963, 42, 1261. 
4. Rector, F. C., Jr., G. van Giesen, F. Kiil, and D. W. Seldin. Influence of expansion of extracellular volume on tubular reabsorption of sodium independent of changes in glomerular filtration rate and aldosterone activity. J. clin. Invest. 1964, 43, 341.

5. Ladd, M., and L. G. Raisz. Response of the normal dog to dietary sodium chloride. Amer. J. Physiol. 1949, 159, 149.

6. Davis, J. O., and D. S. Howell. Mechanisms of fluid and electrolyte retention in experimental preparations in dogs. II. With thoracic inferior vena cava constriction. Circulat. Res. 1953, 1, 171.

7. Goldsmith, C., H. K. Beasley, P. J. Whalley, F. C. Rector, Jr., and D. W. Seldin. The effect of salt deprivation on the urinary concentration mechanism in the dog. J. clin. Invest. 1961, 40, 2043.

8. McDonald, R. H., Jr., L. I. Goldberg, J. L. McNay, and E. P. Tuttle, Jr. Effects of dopamine in man: augmentation of sodium excretion, glomerular filtration rate, and renal plasma flow. J. clin. Invest. $1964,43,1116$.

9. Thompson, D. D., and R. F. Pitts. Effects of alterations of renal arterial pressure on sodium and water excretion. Amer. J. Physiol. 1952, 168, 490.

10. Goodyer, A. V. N., and C. A. Jaeger. Renal response to nonshocking hemorrhage. Role of the autonomic nervous system and of the renal circulation. Amer. J. Physiol. 1955, 180, 69.

11. Dirks, J. H., W. J. Cirksena, and R. W. Berliner. The effect of saline infusion on sodium reabsorption by the proximal tubule of the dog. J. clin. Invest. 1965, 44, 1160.

12. Pitts, R. F. The effects of infusing glycine and of varying the dietary protein intake on renal hemodynamics in the dog. Amer. J. Physiol. 1944, 142, 355.

13. Kiil, F., K. Aukland, and H. E. Refsum. Renal sodium transport and oxygen consumption. Amer. J. Physiol. 1961, 201, 511.

14. Nelson, D. H. Relative merits of the adrenocortical steroids. Ann. Rev. Med. 1962, 13, 241.

15. Gann, D. S., and H. K. Wright. Increased renal sodium reabsorption after depletion of the extracellular or intravascular fluid volumes. J. surg. Res. 1966, 6, 196.

16. Earley, L. E., and R. M. Friedler. Observations on the mechanism of decreased tubular reabsorption of sodium and water during saline loading. $\mathrm{J}$. clin. Invest. 1964, 43, 1928.
17. Earley, L. E., and R. M. Friedler. Changes in renal blood flow and possibly the intrarenal distribution of blood during the naturiuresis accompanying saline loading in the dog. J. clin. Invest. 1965, 44, 929.

18. Earley, L. E., and R. M. Friedler. Studies on the mechanism of natriuresis accompanying increased renal blood flow and its role in the renal response to extracellular volume expansion. J. clin. Invest. 1965, 44, 1857.

19. Earley, L. E., and R. M. Friedler. The effects of combined renal vasodilatation and pressor agents on renal hemodynamics and the tubular reabsorption of sodium. J. clin. Invest. 1966, 45, 542.

20. Shuster, A., E. A. Alexander, R. C. Lalone, and N. G. Levinsky. Renal blood flow, sodium excretion and concentrating ability during saline infusion. Amer. J. Physiol. 1966, in press.

21. Johnston, C. I., and J. O. Davis. Evidence from cross circulation studies for a humoral mechanism in the natriuresis of saline loading. Proc. Soc. exp. Biol. (N. Y.) 1966, 121, 1058.

22. Lassiter, W. E., M. Mylle, and C. W. Gottschalk. Net transtubular movement of water and urea in saline diuresis. Amer. J. Physiol. 1964, 206, 669.

23. Giebisch, G., R. M. Klose, and E. E. Windhager. Micropuncture study of hypertonic sodium chloride loading in the rat. Amer. J. Physiol. 1964, 206, 687.

24. Glabman, S., H. S. Aynedjian, and N. Bank. Micropuncture study of the effect of acute reductions in glomerular filtration rate on sodium and water reabsorption by the proximal tubules of the rat. J. clin. Invest. 1965, 44, 1410.

25. Rector, F. C., Jr., F. P. Brunner, and D. W. Seldin. Mechanism of glomerulotubular balance. I. Effect of aortic constriction and elevated ureteropelvic pressure on glomerular filtration rate, fractional reabsorption, transit time, and tubular size in the proximal tubule of the rat. J. clin. Invest. 1966, 45, 590.

26. Brunner, F. P., F. C. Rector, Jr., and D. W. Seldin. Mechanism of glomerulotubular balance. II. Regulation of proximal tubular reabsorption by tubular volume, as studied by stopped-flow microperfusion. J. clin. Invest. 1966, 45, 603.

27. Cortney, M. A., M. Mylle, W. E. Lassiter, and C. W. Gottschalk. Renal tubular transport of water, solute, and $\mathrm{PAH}$ in rats loaded with isotonic saline. Amer. J. Physiol. 1965, 209, 1199. 